\title{
Bericht van de innerlijke stem Synchronie en diachronie van de heb-zoiets-van-
}

\section{constructie}

\begin{abstract}
In recent and colloquial Dutch, quotations are often introduced by the formula Ik heb zoiets van, similar to English I'm like. This formula can be characterized as a constructional idiom within the framework of construction grammar. Although the combination of elements seems to be novel, and the use of quotative marking follows a world-wide global trend, all parts of the construction can be shown to go back a long way in the diachronic grammar of Dutch. The quotative marker van in particular is argued to have been fairly common at least for a century. A careful analysis of the components of the construction and its relation to other constructions sheds light on its structural properties, and the origin and organization of its meaning.
\end{abstract}

Hij mag zich pas de laatste jaren in een twijfelachtige ${ }^{1}$ aandacht verheugen: de constructie ik heb zoiets van (voortaan kortweg de heb-zoiets-van-constructie), zoals in:

$$
\text { Ik heb zoiets van ja ik weet niet }
$$

Deze constructie zou in de jaren 80 van de twintigste eeuw ontstaan zijn (Hengeveld 1994) als een bijzondere constructie met het al oudere "quotatieve van" (Van Alphen 2006, Foolen e.a. 2006, Foolen 2006), dat op zijn beurt voor het eerst in de linguïstische literatuur besproken is door Verkuyl (1976), die het overigens het "performatieve van" noemde (zoals later ook Van den Toorn e.a. 1997 dat deden).

* Adres van de auteur: Radboud Universiteit Nijmegen, afdeling Taalwetenschap, postbus 9103, 6500 HD Nijmegen, e-mail: P.A.Coppen@let.ru.nl. Graag dank ik Ad Foolen en de anonieme reviewers van Nederlandse Taalkunde voor hun commentaar op (een) vorige versie(s) van dit artikel.

1 Deze aandacht strekt zich uit van de meer serieuze taalkundige aandacht tot de meest heftige taalkritiek van het brede publiek. 
Het is evident dat het hier een idiomatische constructie betreft: vrijwel alle componenten (hebben, zo, iets, van) staan vast, en de betekenis lijkt niet zonder meer voorspelbaar uit de samenstellende delen. Daarom ligt een beschrijving in het kader van de recente constructiegrammatica (Jackendoff 1995, Goldberg 1995, Verhagen 2005) voor de hand. In dat kader kan de constructie voorlopig als volgt beschreven worden:

\section{[(zo)iets hebben van $\mathrm{CP}] \quad$ "Een gevoel hebben dat te omschrijven is met CP"}

Deze beschrijving roept echter een aantal vragen op: het is bijvoorbeeld de vraag wat de status is van (zo)iets, of van CP niet een nabepaling bij iets is en dus thuishoort vóór hebben, of hebben wel de enige mogelijkheid in het paradigma is, en of de aangegeven omschrijving wel precies de betekenis uitdrukt. Daarnaast is het binnen de constructiegrammatica een centrale kwestie welke relaties deze constructie heeft met andere constructies in de synchrone en diachrone grammatica van het Nederlands.

In dit artikel zal ik deze vragen beantwoorden. In paragraaf 2 ga ik nader in op verwante constructies met hebben, in paragraaf 3 bespreek ik de functie van het quotatieve van, en in paragraaf 4 onderzoek ik de rol van het element zoiets. Ten slotte stel ik in paragraaf 5 de rol van het citaat aan de orde, en kom ik tot een bijstelling van de beschrijving in $(2)$.

\section{Het werkwoord hebben}

Het gebruik van het werkwoord hebben in de heb-zoiets van-constructie sluit aan, zoals Coppen (1994) opmerkte, bij de gebruikswijze die je zou kunnen omschrijven met het "ervaringswerkwoord hebben."

(3) Ik heb het idee, het gevoel, de griep, honger, verdriet, plezier...

In de omschrijving van het WNT, betekenis I, (I) A 5:

Het object is de eene of andere lichamelijke aandoening of geestelijke ondervinding, en door hebben wordt aangeduid, dat het subject daarmede is bedeeld (hetzij er mede belast, er door gekweld, of: er mede beweldadigd, "gezegend"). Vandaar voor hebben de bet.: lijden, ondergaan, ondervinden, en: genieten, ervaren, beleven.

In de voorbeelden van het WNT gaat het om "lichamelijke, meest ziekelijke ongesteldheid," maar ook "met betrekking tot de gewaarwording, het gevoel van koude, warmte, honger enz." Dat is exact waar het nu nog in de heb-zoiets van-constructie om gaat. Wie "iets heeft van..." beschrijft een gevoel. Van Alphen (2006) noteert vooral citaten met een negatieve betekenis die in haar corpus volgen op deze constructie. Zo'n negatieve bias kan natuurlijk heel goed een echo zijn van het "meest ziekelijke" dat het WNT signaleert.

Dit ervaringswerkwoord hebben lijkt weer een bijzondere instantie van een algemener, meer existentieel "light verb" hebben, dat ook al in het WNT opgetekend staat, in betekenis I, (I) C: 
In de meest verzwakte opvatting, t.w. waar hebben niet heel veel meer beteekent dan juist even het tegenovergestelde van missen of ontberen, verstoken zijn, derhalve niet heel veel anders aanduidt, dan dat het object er voor het subject is, bestaat.

Onder deze betekenis vallen allerlei idiomen als Daar zul je het hebben!, Dat hebben we gehad, Ik had 't niet meer, Ik had het helemaal gehad! maar ook verbindingen als een bezigheid hebben, gemeenschap hebben, en zelfs small clauses als in:

(4) [een kind op schoot] hebben

(5) [een boek vóór zich] hebben

Het WNT rekent ook constructies met een meer werkwoordelijk karakter onder deze groep:

(6) schulden hebben uitstaan

(7) geld op de spaarbank hebben staan

(8) zijn hoed boven hebben liggen

De subjectpredicaatverbinding in de small clauses in (4-8) wordt hier voorgesteld als een situatie of gebeurtenis, die op de een of andere manier gerelateerd is aan het onderwerp van hebben. Dat kan een vage bezitsrelatie zijn (zoals met het geld op de spaarbank), maar het kan ook alleen maar iets zijn wat deze persoon heeft meegemaakt. Ook deze semantiek sluit vrijwel naadloos aan op de huidige gebruikswijze. Het WNT-artikel stamt uit 1901.

Een verwant geval dat niet in het WNT staat opgetekend, maar dat wel in Coppen (1994) wordt gesignaleerd is:

Je hebt wel eens dat het net begint te regenen als je de deur uit gaat.

In deze constructie (met verplichte modaalpartikels) is het complement van hebben een finiete dat-zin. Deze constructie komt ook vaak voor met voorlopig lijdend voorwerp in de vorm van het woordje dat, in topicpositie: ${ }^{2}$

2 In de traditionele grammatica is het de vraag of het hier een constructie met lijdend voorwerp betreft, dan wel een constructie waarin dat het eigenlijke lijdend voorwerp is en de bijzin een herhalend lijdend voorwerp, maar los van de vraag of dit een interessante kwestie is, kan opgemerkt worden dat in de variant met het anaforisch element in het midden van de zin alleen de vorm het, en niet dat, acceptabel lijkt:

(i) *?Ik heb dat weer, dat ik juist die kaart moet trekken.

(ii) Ik heb het weer, dat ik juist die kaart moet trekken.

(iii) *?Je hebt dat wel eens, dat bepaalde dagen of situaties kloppen.

(iv) Je hebt het wel eens, dat bepaalde dagen of situaties kloppen.

Zeker met nadruk op dat (hetgeen kenmerkend is voor de constructie met herhalend lijdend voorwerp), lijken de zinnen met dat onacceptabel. Dat ondersteunt de gedachte dat (10) en (11) gevallen van getopicaliseerd voorlopig lijdend voorwerp zijn. De volle vorm dat kan dan verklaard worden door de onmogelijkheid van de gereduceerde vorm het in topicpositie. 
(10) Dat heb ik weer dat ik juist die kaart moet trekken (http://forum.fok.nl/ topic/940589/2/50)

(11) Dat heb je toch wel eens? Dat bepaalde dagen of situaties kloppen? Nou, dit was zo'n situatie. (Dolly Dot Patty Zomer, in een interview in De Pers, maandag 14 mei 2007)

Het "light verb" hebben is dus een werkwoord waarvan het complement een toestand of feitelijke gebeurtenis beschrijft die door het subject op de een of andere manier ervaren wordt. Dat complement kan uitgedrukt zijn in een NP, maar ook in een subject-predicaatverbinding in de vorm van een small clause of zelfs een finiete bijzin. De heb-zoiets-vanconstructie valt wat het gebruik van het werkwoord hebben betreft onder een al eeuwen bestaande gebruikswijze.

De meeste gebruikswijzen van het werkwoord hebben vertonen in hun paradigma ook de inchoatieve variant krijgen en de duratieve variant houden. En inderdaad lijken deze varianten ook mogelijk in de heb-zoiets-van-constructie:

(12) Ik krijg zoiets van "Breek me de bek niet open, joh"

(13) Ik hou toch zoiets van "Ik weet het niet"

Deze relatie tussen al deze light verb-constructies met hebben, krijgen en houden (hier samengevat met hebben ${ }_{*}$ ) en de heb-zoiets-van-constructie kan binnen de constructiegrammatica worden uitgedrukt in een zogeheten inheritance tree (Goldberg 1995): een afhankelijkheidsstructuur waarin lagere elementen de eigenschappen van hogere elementen "erven".

De inheritance tree drukt uit dat bepaalde eigenschappen van de lager gelegen elementen voorspelbaar zijn uit de relatie die ze met de hoger gelegen elementen hebben:

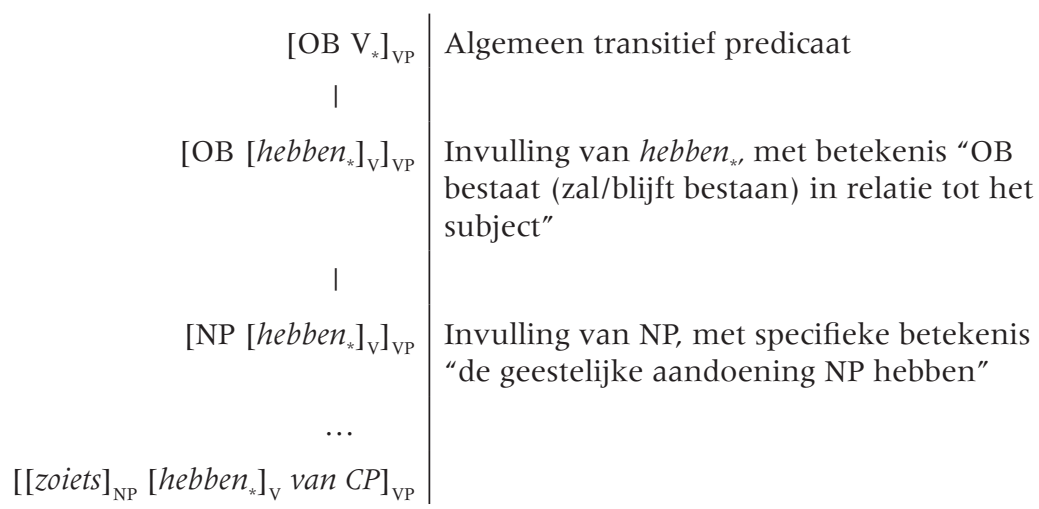

De constructie [NP hebben*] heeft weliswaar een bredere betekenis dan "een geestelijke aandoening hebben," maar de overerving naar de heb-zoiets-van-constructie gaat juist via de variant met deze specifieke betekenis. Aldus vormen de specifieke invullingen van de algemene transitieve werkwoord-voorwerpconstructie in deze inheritance tree de eerste 
contouren van het netwerk van constructies waarvan uiteindelijk de heb-zoiets-van-constructie de meest specifieke invulling is.

In paragraaf 4 kom ik terug op de precieze betekenis van de invulling van zoiets van $C P$ voor NP. In de volgende paragraaf bespreek ik eerst de rol van het quotatieve van.

\section{Het quotatieve zoiets van}

\subsection{Geschiedenis en oorsprong van het quotatieve (zoiets) van}

In alle publicaties over de heb-zoiets-van-constructie en het quotatieve (zoiets) van wordt de indruk gewekt dat de hele constructie een zeer recent verschijnsel betreft. Hengeveld (1994) dateert de heb-zoiets van-constructie op de tweede helft van de jaren tachtig (in de twintigste eeuw), en als er al onderzoekers opmerken dat bijvoorbeeld het quotatieve van al langer bestaat, dan leggen ze in hun bespreking toch meestal het accent op de recente populariteit.

In Foolen e.a. (2006) wordt echter al expliciet afstand genomen van de claim dat het quotatieve van een recent verschijnsel is:

Het gebruik van van dat hier aan de orde is [i.e. het quotatieve van], wordt doorgaans als relatief nieuw en vaak als ongewenst beschouwd. Maar het is zeker niet uit de lucht komen vallen, het wortelt in oudere gebruikswijzen. (Foolen e.a. 2006)

Voorts signaleren Foolen e.a. (2006), in navolging van Güldeman (2001), dat quotatieve markeerders vaak uit similatieve betekenissen ontstaan. Güldeman (2001) observeert dit voor Afrikaanse talen, maar ook het Engelse similatieve like heeft een quotatieve gebruikswijze ontwikkeld in de vorm van:

(15) She was like "oh my gosh no way!"

Een soortgelijke ontwikkeling zou aan de basis van het quotatieve van kunnen hebben gelegen. Wanneer die ontwikkeling zou hebben plaatsgehad is onduidelijk. Foolen e.a. (2006) volstaan met de opmerking dat "het gebruik [...] in de jaren 70 van de vorige eeuw (dat is dus de twintigste eeuw, PAC) [...] al op ruime schaal bestond" en citeren Zaalberg (1986), die zich voorzichtig afvraagt of het wel echt een nieuw verschijnsel is. Zaalberg veronderstelt vervolgens dat "de ouderdom zal kunnen worden vastgesteld door onderzoek in de archieven van radio en televisie; daar is levende spraak betrouwbaar vastgelegd."

Van den Toorn e.a. (1997) verklaren weliswaar onomwonden dat "de constructie [i.e. de constructie met quotatief van, PAC] al in de 19e eeuw met zekerheid is aan te wijzen," maar ze voegen daar haastig aan toe dat "het niet overdreven [is] te stellen dat het gebruik van dit expletieve (overbodige) of performatieve (op een taalhandeling betrokken) van toeneemt." Zij veronderstellen verder een verband met het gebruik van van "bij de weergave van geluiden" (van tik tak tik) en bij ontkenning en bevestiging (van ja/wel, en van nee) niet). 
Aldus lijkt de communis opinio dat het quotatieve van (en zeker zoiets van) tot diep in de tweede helft van de twintigste eeuw hoogstens een marginaal verschijnsel in de spreektaal is geweest, dat passend in een mondiale trend (zie Foolen 2008) in het recente verleden in opmars is geraakt. Dit nu lijkt in tegenspraak met de feiten.

In de snel uitdijende Digitale Bibliotheek voor de Nederlandse Letteren kun je vrij snel voorbeelden vinden die aanzienlijk ouder zijn dan de jaren 70 van de vorige eeuw. Zelfs als we ons beperken tot het quotatieve zoiets van zijn er voorbeelden uit de jaren 50 (cursivering telkens van mij):

(16) De oudste, die ik later in de eetzaal met Herr General hoorde aanspreken, drukte zijn monocle in zijn oog en riep zo iets van: 'Ach so, der junge Künstler'. (Han B. Aalberse, De liefde van Bob en Daphne. Oisterwijk, Den Haag 1955, $2^{\text {de }}$ druk)

(17) Bij het prieel aan de waterkant legde ik mijn arm rond haar schouders, losjes, ik kon nog alle kanten op met die arm en zei zoiets van: 'En dit is zeker je droompaleisje?' (Han B. Aalberse, De liefde van Bob en Daphne. Oisterwijk, Den Haag $1955,2^{\text {de }}$ druk)

Maar ook in de jaren 40 (bijvoorbeeld in de vele oorlogsdagboeken die gepubliceerd zijn) was het verschijnsel niet ongewoon:

(18) Wij namen een aanloop, maar terwijl wij die namen, kregen wij een gevoel van onzekerheid, zo iets van: je haalt het niet. (Joris van den Bergh, Mysterieuze krachten in de sport, 1941)

(19) Hij slaat zich ervan op de dijen en roept zoiets van 'Holla hoera!' van de leut; (Jan de Hartog, Hollands Glorie, 1940)

(20) Wat zullen de westelijke geallieerden daarop moeten antwoorden? Zo iets van: we hebben jelui toch wapenen gestuurd? (Martinus Nijhoff, Dagboekfragmenten 1940- 1945)

Ook in de briefwisseling tussen Ter Braak en Du Perron wemelt het van de quotatieve zoiets vans (vooral bij Du Perron). We zitten dan inmiddels in de jaren 30 van de vorige eeuw:

(21) Die Mult.-historie is een tegenvaller; maar wat mij het meest getroffen heeft is de onaardige manier van reageeren van Jan; zooiets van: weet je niet dat Saks een veel grooter naam heeft dan jij, mannetje? (E. du Perron aan M. ter Braak, 1937)

Ook in de essaybundel De Smalle mens (gepubliceerd in Forum, jaargang 1933) komt het voor:

(22) Hij zegt natuurlik op een vage manier zoiets van 'toch meer.' (E. du Perron, De smalle mens. In: Forum: 1933).

Het betreft hier geen incidenten. DBNL bevat een hele serie jeugdboeken uit het begin van de twintigste eeuw. En ook hier weer een overdaad aan quotatief zoiets van: 
(23) Vrouw Jannetje mopperde ook wel zoo iets van: 'Jongens, die zoo lastig waren en je voortdurend voor de beenen liepen,' maar wegjagen deed ze je niet en als we vroegen: 'Vrouw Jannetje, mag ik een peer?' (Cor Bruijn, Langs den waterkant. Gebr. Kluitman, Alkmaar 1918)

(24) - En zei ze wat?

- Ja zooiets van 'die jongens doen geen kwaad' en 'mag je niet doen'. (C.M. van Hille-Gaerthé, Onder het stroodak, ca. 1917)

(25) Eddy bromde zoo iets van 'flauw kind' en 'lees jij maar zelf je briefje van Jaap Blooker!' maar hij liet het epistel, waar het was: bij het artikel van Bob T. (J.B. Schuil, De A.F.C.-ers. H.J.W. Becht, Amsterdam z.j., 1915)

(26) Kees bromde zoo iets van: 'In geen 100 jaar!' en ging daarop met Eddy naar de Walden's, waar Bram Heesink, de meisjes Van Dieren en Wiesje Borger al op hen wachtten. (J.B. Schuil, De A.F.C.-ers. H.J.W. Becht, Amsterdam z.j., 1915)

(27) Maar de advertentieman prevelde zooiets van: 'da's jammer'. (Kees Valkenstein, De aeroplaan van m'nheer Vliegenthert. W. de Haan, Utrecht z.j., 1910)

Er wordt heel wat afgemopperd, gebromd en gepreveld in deze boeken. Overigens blijkt daaruit dat het vooral gaat om een weergave van onduidelijke spraak.

Het volgende voorbeeld, zelfs met het iets hebben vlak in de buurt, is uit 1900:

(28) Mevrouw, die heel groot en forsch was en iets beslists in haar stem en manieren had, zoo iets van, ìk zeg 't en daarmee uit! (Tine de Kruyff-Gobius, Het Indische nichtje, 1900)

Hier is duidelijk sprake van de constructie [NP hebben] met de betekenis "een geestelijke aandoening hebben, een gevoel hebben," waarbij dat gevoel eerst wordt benaderd met de omschrijving iets beslists, en later met de quotatie iets van ik zeg 't en daarmee uit. Dit komt wel heel dicht in de buurt van de constructie die Hengeveld (1984) dateerde op tachtig jaar later.

Maar ook daar houden de vindplaatsen niet op. Zoals Van den Toorn e.a. (1997) al over het quotatieve van opmerkten, wordt ook zoiets van in de negentiende eeuw al aangetroffen:

(29) Veel menschen, de mooie geslepen glazen, wijn! Pa rood en glimmend van pret, mij telkens een knipoogje gevend, zoo iets van: 'Hoe voel je je nu, meid?' (Tine van Berken, Een klaverblad van vier. H.J.W. Becht, Amsterdam z.j., 1894)

(30) Ik hoorde zoo iets van; 'die andere kerel is weg en hij liet dat olde mensch op de brugge staon en ie gaf er niks.' (Willem Bastiaan Tholen in een brief aan Willem Witsen, 21 oktober 1885)

De vroegste quotatieve zoiets van die ik heb aangetroffen is de volgende:

(31) Eindelijk toch hoorde moeder buurmans gebrom. Zij verstond zoo iets van kwâjongens, die de ouders maar laten loopen, en die nergens hunne handen af kunnen houden. (C.E. van Koetsveld, Verspreide kinderverhalen. S.E. van Nooten, Schoonhoven z.j., 1855) 
De conclusie moet zijn dat het quotatieve zoiets van al zeker sinds de negentiende eeuw in de spreektaal bestaat. Ik neem aan dat het quotatieve van (zonder zoiets) nog ouder is, maar het is lastig om goede voorbeelden te vinden. In elk geval is de combinatie van jae en van neen al eeuwenlang regelmatig aan te treffen, in combinatie met verba dicendi (seide of antwoordde). In de op het internet gepubliceerde dagboeken van Willem Frederik, stadhouder van Friesland, Groningen en Drenthe, uit 1647, staan er verschillende:

(32) Gemmenich bij mij geweest, sprack mij van de cornetzplaetz, of hij nae Wesel soude gaen; ick seide van jae, hij most sich laeten voorstellen; hij had gehoort, dat prins Wilhelm daer al in versien had; ick seide ick had het oock gehoort, doch het kompt hem niet toe te vergeven. (Willem Frederik, Gloria parendi. Dagboeken van Willem Frederik, stadhouder van Friesland, Groningen en Drenthe, 1647)

Het lijkt erop dat althans de rudimenten van het quotatieve van tot de spreektaal van die tijd hebben behoord. In elk geval kan er ernstige twijfel bestaan over de stelling dat het quotatieve van, of zelfs zoiets van, voornamelijk een eind-twintigste-eeuws verschijnsel zou zijn. Het lijkt me zeer aannemelijk dat het quotatieve van in de spreektaal al veel eerder vrij normaal was. In dit verband is het illustratief dat veel van de schriftelijke vindplaatsen juist uit de jeugdliteratuur en egodocumenten afkomstig zijn. Deze genres mogen geacht worden dichter bij de spreektaal te staan dan de meer literaire genres.

\subsection{De woordsoort van van}

Zoals eerder opgemerkt beperkt de taalkundige literatuur zich veelal tot een analyse van het quotatieve van. Daarbij wordt van gezien als een voegwoord (of complementizer, zoals in Verkuyl 1976, Hengeveld 1994 en Van der Wouden e.a. 2002), dan wel als een voorzetsel (bijvoorbeeld Van der Horst 1982). Ook wordt soms volstaan met de vaststelling dat van een quotative marker is, hetgeen de categoriale status enigszins in het midden laat en ook de mogelijkheid tot bijvoorbeeld een partikelstatus openhoudt.

In elk geval kan syntactisch ondubbelzinnig vastgesteld worden dat van met het daaropvolgende citaat één zinsdeel vormt:

(33) Ik heb altijd zoiets gehad van dat zal wel

(34) *Ik heb altijd zoiets van gehad dat zal wel

(35) ?Ik heb altijd zoiets van dat zal wel gehad

(36) Niet een keer tijdens het afspelen van de cd heb ik zoiets van "zappen" gehad. Het luistert gewoon heel lekker weg.

Deze voorbeelden tonen aan dat van niet te splitsen is van het citaat (zoals in (34)), en dat zelfs het citaat samen met van vóór de werkwoordelijke eindgroep kan voorkomen (wat uitzonderlijk is voor sententiële zinsdelen). Voorbeelden van zo'n zinsintern citaat zijn weliswaar zeldzaam, maar (36) is letterlijk geciteerd (inclusief aanhalingstekens) van een consumentenforum op het internet.

Van moet dus inderdaad gezien worden als voegwoord of als voorzetsel. Van der Horst (1982) voert aan dat het voorzetsel van in allerlei betekenisarme gebruikswijzen voor- 
komt, en dat in de quotatieve gebruikswijze niet veel meer gedaan wordt dan het leggen van een vage relatie tussen het werkwoord en het citaat. Hengeveld (1994) en Verkuyl (1976) wijzen op het sententiële karakter van wat volgt en opteren daarom voor de voegwoordanalyse.

Van als voegwoord wordt weliswaar al vermeld in het WNT (en Van Dale neemt het voorbeeld vrijwel letterlijk over), maar dit lijkt een compleet ander woord:

(37) Loop zeere naar de schole, van anders komde te late (WNT, lemma van III, voorbeeld geciteerd uit de Dialectatlas van West-Vlaanderen en Frans-Vlaanderen, 1947)

Hier is eerder sprake van een redengevende betekenis dan van quotatiefmarkering. ${ }^{3}$

De voegwoordanalyse van van lijkt geïnspireerd door constructies als de volgende (alle voorbeelden van het internet):

(38) Mijn moeder zei van dat ze voorzichtig moest doen.

(39) Ik schrijf van dat ik de allergrootste ruziemaakster van de wereld kan zijn.

(40) Daarom geeft het Gentse Steunpunt Kraken advies aan al wie erover denkt van te beginnen kraken.

(41) Als je denkt van te kunnen ontsnappen...

(42) R. zei van te wachten want het is het zeker waard

In (38-39) wordt van gecombineerd met een finiete bijzin (inclusief voegwoord dat). In (40-42) lijkt van de positie van het onderschikkende om bij een beknopte bijzin in te nemen, maar in Van Craenenbroeck (2000) wordt deze oppervlakkige observatie genuanceerd: het heeft eigenschappen van zowel voorzetsel als voegwoord.

De voorbeelden (38-39) lijken inderdaad verwant aan het quotatieve van, maar ze bewijzen natuurlijk niet dat van een voegwoord is. In deze specifieke voorbeelden spreekt zelfs het feit dat het voegwoord dat naast van aanwezig is, tegen deze opvatting. De verwantschap tussen het quotatieve van en het "Vlaamse van" in (40-42) is in ieder geval kleiner. Van Craenenbroeck (2000) toont aan dat er bij het "Vlaamse van" ook mogelijkheden tot extractie uit het citaat zijn, die bij het quotatieve van ontbreken.

Hoewel de voorzetselstatus van het quotatieve van moeilijk syntactisch te onderbouwen is, geloof ik dat de voegwoordanalyse hoe dan ook slechtere papieren heeft. Als van de complementizer van het citaat zou zijn, zou je verwachten dat zinsinitiële vraagwoorden, die immers vóór het voegwoord staan, ook vóór het quotatieve van zouden komen. Dat is zeker niet het geval:

3 Het WNT merkt hierover op: “Dit woord, dat voor het taalgevoel een bijvorm is van het voegw. want, is blijkbaar identiek met het voorz. van als aanduiding van de oorzaak, de reden [...], b.v. van ellende omkomen; vandaar ook in het vl. het gebruik van het voorz. van gevolgd door een redengevenden bijzin: ik ben hem dankbaar van dat hij mij zo dikwijls bezocht heeft." Het ligt buiten het bestek van dit artikel om hier nader op in te gaan. 
(43) Ik had bij dit boek ook soms zoiets van "waar gaat het over" (uit een boekverslag op www.scholieren.com)

(44) Ik vroeg me bij dit boek af waar (of) (dat) het over ging

Zelfs in het geval van een meervoudige complementizer (zoals of dat in (44)) gaat het vraagwoord aan alle complementizers vooraf, ${ }^{4}$ maar dus niet aan het quotatieve van.

Daarnaast gaat het bij het citaat in de meeste gevallen ${ }^{5}$ over een directe rede, die gekenmerkt wordt door Verb Second. Het is bekend dat Verb Second een complementaire distributie vertoont met onderschikkende voegwoorden. In generatieve analyses wordt dit meestal verklaard door aan te nemen dat het finiete werkwoord de plaats inneemt van het voegwoord. Dat betekent dat onder een generatieve analyse de stelling dat van een complementizer is, alleen al op grond van het voorkomen van Verb Second in het citaat onhoudbaar is. Maar ook zonder een generatieve analyse is de observatie dat geen enkel onderschikkend voegwoord kan voorkomen in combinatie met verb second een argument om van geen onderschikkend voegwoord te noemen. ${ }^{6}$

De beste syntactische analyse van het quotatieve van lijkt dus het voorzetsel. Hoewel extreem zeldzaam, lijkt zelfs de variant met voornaamwoordelijk bijwoord niet onmogelijk:

$\mathrm{Nu}$, Aart had daar ook iets van en hij beloofde bij zijn afscheid dan ook, dat als zij door de Heere mocht worden weggenomen, hij haar mee zou komen begraven. ${ }^{7}$

Het betreft hier maar een enkel geval, maar het is een ondubbelzinnig voorbeeld van een voorzetsel van in de heb-zoiets-van-constructie.

Ook in de combinatie met iets lijkt de voorzetselanalyse van van de meest waarschijnlijke. Naast het quotatieve zoiets van komen immers ook varianten voor als:

4 Hoewel Van Craenenbroeck (2000) het Vlaamse van wél als complementizer lijkt te beschouwen, analyseert hij het in Van Craenenbroeck (2002) als voorzetsel. Dat strookt met de hier gevolgde redenering. Ook bij het Vlaamse van lijkt in alle-geconstrueerde- gevallen plaatsing van een vraagwoord achter van stukken beter:

(i) *Mijn moeder vroeg hoe voorzichtig van hiermee te moeten zijn.

(ii) ?Mijn moeder vroeg van hoe voorzichtig hiermee te moeten zijn.

(iii)*Hij vroeg hoelang van te moeten wachten.

(iv)?Hij vroeg van hoelang te moeten wachten.

Ook al heb ik geen voorbeelden van vraagwoorden in deze constructie kunnen vinden, de varianten met vraagwoord vóór van zijn evident onmogelijk. Als van hier een voegwoordelijke projectie is, dan zit die projectie in ieder geval boven de projectie die het vraagwoord mogelijk maakt (i.c. de "normale" voegwoordprojectie).

5 Ook varianten met indirecte rede komen voor, zoals $I k$ heb zoiets van dat het misschien een fake is (voorbeeld van het internet), maar deze zijn veel minder frequent: een googletelling van ik heb zoiets van levert ongeveer 7000 treffers op, ik heb zoiets van dat gevolgd door een indirecte rede precies 20 (handmatig gecheckt).

6 Het zou theoretisch nog te overwegen zijn om van als een nevenschikkend voegwoord te analyseren, maar dat lijkt me niet de bedoeling van de in de literatuur voorgestelde analyses, en bovendien zou een dergelijke analyse in de problemen komen vanwege het ontbreken van samentrekkingsverschijnselen en de ondergeschikte functie van het citaat.

7 Het voorbeeld is van www.theologienet.nl. In de alinea voorafgaand aan het citaat wordt een overweging geschilderd die men kan hebben bij de dood van een dierbare. 
(46) Men krijgt dan zooiets van weeheid over al dit zinneloos gemor (De Gids, 1898)

(47) En zij glimlachte, Constance, want er was zoo iets van vrede in huis, daar in die kamer, iets bijna van geluk, klein geluk, als de menschen wel eens vinden, een kort oogenblik. (Louis Couperus, De boeken der kleine zielen, 1903.)

In deze constructies is er duidelijk sprake van een PP die bestaat uit het voorzetsel van met een NP-complement. De betekenis is approximatief: de precieze betekenis van de NP wordt benaderd door de constructie zoiets van. In de quotatieve heb-zoiets van-constructie is het niet wezenlijk anders.

Ten slotte kan een verband worden verondersteld met een partitieve genitief als in:

We hebben iets lekkers gegeten.

De genitief die afhankelijk is van woorden als iets, wat, en veel is al erg oud. De betekenis van iets lekkers is te omschrijven als "iets wat lekker is." ${ }^{8}$ Vervanging van die partitieve genitief door een constructie met van komt vaker voor:

(49) Ik zag iets blauws in dat schilderij.

(50) Ik zag iets van blauw in dat schilderij.

(51) Hij had iets waardevols gekocht.

(52) Hij had iets van waarde gekocht.

Het gebruik van het quotatieve van, in ieder geval aansluitend bij (zo)iets, is zo in overeenstemming met de meeste andere gebruikswijzen van de genitief die vervangen worden door het voorzetsel van. ${ }^{9}$ Ook dat is een argument om het quotatieve van als voorzetsel te beschouwen.

In voorbeeld (28) wordt het verband tussen de partitieve genitief en zoiets van wel heel sterk geïllustreerd. Ik herhaal het voorbeeld hier, met de relevante elementen gecursiveerd:

(53) Mevrouw, die heel groot en forsch was en iets beslists in haar stem en manieren had, zoo iets van, ìk zeg 't en daarmee uit!

Hier wordt de partitieve genitief iets beslists vrijwel onmiddellijk gepreciseerd tot het quotatieve zoiets van. Er zijn vrij gemakkelijk meer van deze voorbeelden te vinden, ook met vervangende van-constructies. De volgende zijn alle van het internet:

8 Ik spreek hier over een partitieve genitief bij gebrek aan een betere benaming. Volgens Schönfeld (1970) is de constructie met adjectivische genitief ontstaan uit een partitieve genitief, maar Van der Horst (2008) merkt op dat het in het Middelnederlands een wat lossere - splitsbare - constructie betreft. Als mogelijke partitieve betekenis kan verondersteld worden "iets van alles wat lekker is."

9 Voor de goede orde: wat ik in (49-52) op het oog heb is niet de diachrone ontwikkeling van een genitief naar een van-constructie. Wat ik veronderstel is dat in de synchrone grammatica van het hedendaagse Nederlands een vervanging mogelijk is van de genitief in iets blauws in iets van blauw. Het is deze synchrone constructiemogelijkheid die in de iets-van-constructie wordt aangesproken. 
(54) Er kwam gaandeweg bij velen van ons ook iets arrogants boven, zoiets van: wij zijn toch maar kinderen van de Verlichting,

(55) Dat clubje blijft iets speciaals. Zoiets van: wij wisten het al.

(56) Als je op de buhne staat, dan heeft dat iets egoistisch, zoiets van "Kijk hier ben ik dan".

(57) Soms bespeur ik wel iets van groepsgedrag, zoiets van "wij vrijmetselaren".

Deze analyse maakt de volgende uitbreiding van de inheritance tree uit 0 mogelijk:

\begin{tabular}{|c|c|}
\hline$[\mathrm{OB} \mathrm{V}]_{\mathrm{VP}}$ & Algemeen transitief predikaat \\
\hline$\left[\mathrm{OB}[\text { hebben }]_{\mathrm{V}}\right]_{\mathrm{VP}}$ & $\begin{array}{l}\text { Invulling van hebben }{ }_{*^{\prime}} \text { met betekenis "OB } \\
\text { bestaat (zal/blijft bestaan) in relatie tot het } \\
\text { subject" }\end{array}$ \\
\hline I & \\
\hline$\left[\mathrm{NP}[\text { hebben }]_{\mathrm{V}}\right]_{\mathrm{VP}}$ & $\begin{array}{l}\text { Invulling van NP, met specifieke betekenis } \\
\text { "de geestelijke aandoening NP hebben" }\end{array}$ \\
\hline I & \\
\hline$\left[\left[\text { iets } \mathrm{AP}_{\mathrm{GEN}}\right]_{\mathrm{NP}}[\text { hebben }]_{*}\right]_{\mathrm{VP}}$ & $\begin{array}{l}\text { Invulling van de NP met iets+partitieve ge- } \\
\text { nitief, met de betekenis "iets hebben van de } \\
\text { geestelijke aandoening AP" }\end{array}$ \\
\hline I & \\
\hline$\left[\left[\text { iets }[\text { van } \mathrm{X}]_{\mathrm{PP}}\right]_{\mathrm{NP}}[\text { hebben }]_{*}\right]_{\mathrm{VP}}$ & $\begin{array}{l}\text { Vervanging }{ }^{10} \text { van de partitieve genitief door } \\
\text { een PP met van (betekenis volgt in paragraaf } 4 \text { ) }\end{array}$ \\
\hline
\end{tabular}

\subsection{De functie van zo}

Het woordje zo komt behalve in de heb-zoiets-van-constructie wel vaker voor bij quotatieven:

(59) Dus ik zei zo tegen L.: "Laten we al onze tassen op de tafel achter hem zetten."

(60) Remco zei zo van: Niet kijken doen of je niks weet.

Het WNT signaleert deze gebruikswijze rond 1900 al als een informele quotatiefmarkeerder (lemma zo, betekenis I 5a):

10 Zie ook voetnoot 9 . 
In volkst. in deze toep. evenals in de toep. b) vaak gebruikt als (voortdurend herhaalde) stoplap in een relaas van iemands woorden.

Het WNT geeft twee sprekende voorbeelden:

(61) Hij zee zoo da' 'k wa' moest wachten (uit 1903)

(62) 'k En zal nie kommen, zai ze zoo, 'k moet thuisblijven, zai ze zoo, moeder es te ziek, zai ze zoo, 't zal veur nen andere keer zijn, zai ze zoo (voorbeeld uit 1922)

Foolen e.a. (2006) signaleren een quotatief zo dat in het recente Duits voorkomt, maar ook in een aantal Nederlandse regio's:

(63) ... kwam er nog een meisje lags gefiets wat ik kende en ik zo TOKIO HOTEL CONCERT!!!! dus zij lachen en ik zo tegen pap kom op rijden zo hard als je kunt... (lichelle op http://deathlifexth.startspot.nl)

In deze constructie ontbreken de verba dicendi, en het element zo verzorgt als enige element de quotatiefmarkering.

In Schelfhout (2000) wordt de rol van het woordje zo bij zogeheten "reporting clauses" geanalyseerd. Het gaat dan om voorbeelden als:

(64) "We hebben" zo zegt hij, "weer een eigen legioen"

(65) "Sorry meneer," zo duwde Yvette de arm van haar schouder, "maar wij hoeven even niks."

In navolging van Collins \& Branigan (1997) pleit Schelfhout voor een parenthetische (intercalatieve) analyse van de reporting clause (i.c. zo zegt hij, zo duwde Yvette de arm van haar schouder): het citaat is niet het lijdend voorwerp van zeggen of duwen (het lijdend voorwerp van duwen is immers al de arm), maar de reporting clause is een adjunct dat in het citaat geïntercaleerd is. Het element zo is volgens Schelfhout een anaforisch element (Collins \& Branigan spreken van een operator), dat de thematische objectrol van het werkwoord draagt.

De vraag is of het $z o$ in de zinnen (59-63) hetzelfde $z o$ is als dat in de constructie met reporting clauses. Het lijkt in ieder geval structureel verschillend. Bij reporting clauses staat zo altijd in initiële positie, vlak vóór het finiete werkwoord. In (59-63) lijkt deze positie onmogelijk:

(66) * Zo zei ik dus tegen L.: "Laten we al onze tassen op de tafel achter hem zetten."

(67) * Zo zei Remco van: Niet kijken doen of je niks weet.

(68) * ... kwam er nog een meisje langs gefiets wat ik kende en zo ik TOKIO HOTEL CONCERT!!!! dus zij lachen en zo ik tegen pap kom op rijden zo hard als je kunt...

De zinnen (66) en (67) zijn natuurlijk wel grammaticaal, maar alleen in de lezing waarin zo een "normaal" bijwoord is (te parafraseren met "bijvoorbeeld"). Die exemplificerende betekenis ontbreekt in (59-63). 
Schelfhout argumenteert dat de plaatsing van zo op de eerste zinsplaats, vóór het citaat, onmogelijk is, omdat het als anafoor in deze positie zijn antecedent (het citaat) zou c-commanderen. Als dit juist is, kan zo in (59-63) niet als een soortgelijke anafoor worden geanalyseerd, omdat in deze voorbeelden dezelfde structurele relatie tussen zo en het citaat bestaat. Daar komt bij dat de betekenis van zo in (59-63) ook wezenlijk anders is dan in 64 en 65, waar het citaat de letterlijke en ondubbelzinnige weergave is van wat er gezegd is. In (59-63) wordt juist aangegeven dat het citaat niet exact is, maar alleen benadert wat er letterlijk gezegd is. Met andere woorden: $z o$ in (59-63) is approximatief. ${ }^{11}$

Het approximatieve zo is ook in andere gebruikswijzen dan de quotatieve contexten bekend:

(69) Morgen wordt het $z o^{\prime}$ n 25 graden.

(70) Morgen wordt het zo ongeveer 25 graden.

(71) Geef mij eens een potlood of $z o$.

Ook deze betekenissen staan al min of meer vermeld in het WNT (lemma zo, betekenis I 12):

Als "beperkend" bijw. van modaliteit (vgl. OVERDIEP, Stil. Gramm. 430 [1937]), gebruikt om de aanduiding in het woord dat of de woordgroep die erdoor wordt bepaald, een beetje af te zwakken, vager te maken, om aan te geven dat wat wordt gezegd niet op een al te precieze wijze opgevat dient te worden

Met de vroege voorbeelden:

(72) Wij kwamen dan met onze reiskoets, zoo omtrent zeven uren binnen Utrecht, en ook weldra voor het Oude Kasteel van Antwerpen (uit 1805)

(73) Zie, ik ben zo wel wat beschikkig, en regt in myn element, als er zo wat te bezorgen, en zo wat uit te deelen valt (uit 1787)

De combinatie zo wat wordt in dit verband apart vermeld met de betekenis "ongeveer, min of meer":

(74) Toen ik 't eens 's avonds deed — 't is zoo wat een paar weken geleden — kwam ik Mijnheer van Vliet tegen (uit 1852)

Het WNT spreekt in navolging van Overdiep (1937) over "afzwakken, vager maken", maar de voorbeelden zijn niet strijdig met de gedachte dat juist precisering van een vaag gegeven de bedoeling is. In elk geval kan vastgesteld worden dat zo blijkbaar een beroep

11 Foolen e.a. (2006) gebruiken in verband met de heb-zoiets-van-constructie de term similatief. Hoewel het onderscheid subtiel is, en misschien niet eens zo relevant (Vandelanotte 2008 spreekt in verband met het Engelse like van "a cluster of similarity/comparison/approximation"), geloof ik dat approximatief de betere omschrijving is. De functie van de approximatieve aanduiding is immers doelgericht: de bedoeling is om de precisie te benaderen, niet om ervan af te wijken. 
doet op gezamenlijke kennis (“je weet wel”) om tot een precieze betekenis te komen. Dit geldt voor alle vormen van het approximatieve zo, niet alleen in de context van de hebzoiets-van-constructie.

Het lijkt er dus op dat de functie van zo in de heb-zoiets-van-constructie hoofdzakelijk approximatief is: door het gebruik van zo wordt aangegeven dat het citaat dat volgt een benadering is en geen exacte weergave. ${ }^{12}$ Het woordje $z o$ in de heb-zoiets-van-constructie is dus niet hetzelfde zo als in de reporting clause, en zoiets hebben van is niet te beschouwen als een intercalatie bij het citaat. In paragraaf $3.4 \mathrm{kom}$ ik terug op de andere mogelijkheid, namelijk dat het citaat (inclusief van) beschouwd kan worden als een intercalatie bij zoiets hebben.

Dit houdt in dat we de inheritance tree voor de heb-zoiets-van-constructie als volgt kunnen aanvullen:

\begin{tabular}{|c|c|}
\hline $\begin{array}{l}{\left[\mathrm{OB} \mathrm{V}_{*}\right]_{\mathrm{VP}}} \\
\mathrm{I}\end{array}$ & Algemeen transitief predikaat \\
\hline$\left[\mathrm{OB}[\text { hebben }]_{\mathrm{V}}\right]_{\mathrm{VP}}$ & $\begin{array}{l}\text { Invulling van hebben }{ }_{* \prime} \text { met betekenis } \\
\text { "OB bestaat (zal/blijft bestaan) in } \\
\text { relatie tot het subject" }\end{array}$ \\
\hline । & \\
\hline$\left[\mathrm{NP}[\text { hebben }]_{\mathrm{V}}\right]_{\mathrm{VP}}$ & $\begin{array}{l}\text { Invulling van NP, met specifieke be- } \\
\text { tekenis "geestelijke aandoening NP } \\
\text { hebben" }\end{array}$ \\
\hline I & \\
\hline$\left[\left[(z o) \text { iets } \mathrm{AP}_{\mathrm{GEN}}\right]_{\mathrm{NP}}[\text { hebben }]_{\mathrm{V}}\right]_{\mathrm{VP}}$ & $\begin{array}{l}\text { Invulling van de NP met (zo) } \\
\text { iets+partitieve genitief, met de bete- } \\
\text { kenis "(bij benadering) iets hebben } \\
\text { van de geestelijke aandoening AP" }\end{array}$ \\
\hline । & \\
\hline$\left[\left[(z o) \text { iets }[\text { van } \mathrm{X}]_{\mathrm{PP}}\right]_{\mathrm{NP}}[\text { hebben }]_{\mathrm{V}}\right]_{\mathrm{VP}}$ & $\begin{array}{l}\text { Vervanging van de partitieve geni- } \\
\text { tief door een PP met van (betekenis } \\
\text { volgt in paragraaf } 4 \text { ) }\end{array}$ \\
\hline & \\
\hline roiets $\left.]_{\mathrm{NP}}[\text { hebben }]_{\mathrm{V}}[\text { van CP }]_{\mathrm{PP}}\right]_{\mathrm{V}}$ & \\
\hline
\end{tabular}

12 Men zou kunnen aanmerken dat zo meer een demonstratieve functie heeft ("kijk, zo!"), en die functie toepast op de semantiek van het element waar het aan toegevoegd wordt (iets, wat, ' $n$ ). Dat mag een kern van waarheid hebben, maar de observatie is dan dat het demonstratieve zo de latente vaagheid van dat andere element omzet naar een poging tot benadering van precisie. Het verschil tussen ongeveer en zo ongeveer is precies dat het laatste een beroep doet op de gezamenlijke kennis die tot meer duidelijkheid moet leiden. Ongeveer geeft alleen maar vaagheid aan, zo ongeveer een approximatieve vaagheid. 
Het is het woord iets met zijn onbepaalde inhoud dat van een approximatieve betekenis wordt voorzien door zo. Dat kan dus al in de variant met partitieve genitief. Vaak betreft zo'n toevoeging een bepaling met bijzin van graadaanduidend gevolg (zoiets moois dat het pijn aan je ogen deed), maar een zeker voorbeeld is:

(76) Dat was zo iets Tolstoïaans of als de kolonie in 't Goor: je eigen boontjes planten! (Joos Florquin, Ten huize van... 4)

In feite betreft het in (75) de vereenvoudigde weergave van een multiple inheritance tree: de approximatieve constructie met zo vormt een aparte tak die een relatie onderhoudt met de constructie met partitieve genitief, waardoor de mogelijkheden die in deze combinatie toegevoegd worden, overgeërfd worden in alle constructies die weer daaronder staan. In de figuur is dit uitgedrukt door het element zo tussen haakjes in de constructie weer te geven.

\subsection{De functie van iets}

Het woordje iets in de heb-zoiets-van-constructie is zonder twijfel het lijdend voorwerp van het werkwoord hebben (zie ook Vandelanotte 2008). Echter, in de constructie met verba dicendi kan het probleemloos achterwege blijven:

(77) Hij zei (zo)iets van: "Laat maar zitten."

(78) Hij zei zo van: "Laat maar zitten."

(79) Hij zei van: "Laat maar zitten."

(80) Hij zei: “Laat maar zitten".

Dat roept de vraag op waarom dan iets in deze constructie überhaupt toegestaan is. Blijkbaar vervult het citaat in de directe rede de thematische rol van het object al, en lijken ook dwingende naamvalsredenen voor een NP-object te ontbreken. Twee verklaringen dringen zich op:

- $\quad$ Door de aanwezigheid van iets krijgt van behalve de functie van quotatieve markeerder ook een partitieve betekenis; die partitieve betekenis versterkt de approximatieve betekenis: het citaat is geen volledige weergave van wat gezegd wordt, maar een deel daarvan dat wel het oorspronkelijke citaat voldoende karakteriseert;

- $\quad$ De quotatieve markeerder van zorgt ervoor dat het citaat in feite niet meer het lijdend voorwerp is, maar parenthetisch (zie ook de bespreking van Schelfhout 2000 in paragraaf 3.3). Daardoor ontstaat de syntactische behoefte tot invulling van het lijdend voorwerp met een onbepaald voornaamwoord.

Beide verklaringen voldoen in de constructie met verba dicendi, maar in de heb-zoiets-vanconstructie is het patroon anders: 
(81) Ik heb (zo)iets van: "Laat maar zitten."

(82) * Ik heb zo van: "Laat maar zitten."

(83) * Ik heb van: "Laat maar zitten."

(84) * Ik heb: "Laat maar zitten".

In deze constructie is iets verplicht, en blijkbaar is er nu wél een dwingende reden om een NP-object te hebben. Het ligt voor de hand om dit toe te schrijven aan het werkwoord hebben, dat een verplichte naamval voor zijn object genereert.

Blijkbaar hebben verba dicendi een optionele naamval voor een NP-object, terwijl de naamval bij hebben verplicht is. Hebben vereist dus een NP-object. Beide constructies hebben een thematische rol voor het object, die gedragen wordt door het NP-object (als dat aanwezig is), maar die ook gedragen kan worden door een citaat. Maar dat betekent dat het met het quotatieve van gemarkeerde citaat als een parenthetisch element moet worden gezien: het is niet gesubcategoriseerd door het werkwoord, het kan alleen (eventueel samen met NP-object) een thematische rol dragen.

Net als bij de parenthetische analyse van de reporting clause uit Schelfhout (2000) heeft een parenthetische analyse van het quotatief gemarkeerde citaat in de heb-zoiets-vanconstructie iets tegenintuïtiefs. Het citaat heeft een belangrijke functie in de communicatie, en aangezien parenthetische constructies syntactisch weglaatbaar zijn ontstaat gemakkelijk de neiging om te veronderstellen dat ze daarom communicatief ondergeschikt zouden zijn. Deze redenering lijkt me onjuist. De intercalatie in de heb-zoiets-van-constructie is heel goed te lezen als een nadere verduidelijking van de mededeling dat iemand ergens een gevoel bij heeft. Je zegt $I k$ heb zoiets om met een beroep op gezamenlijke kennis een gevoel aan te geven, en dat kun je nader omschrijven met een partitieve genitief (ongemakkelijks), een constructie met van en NP (van boosheid), of een constructie met citaat (van ja ik weet niet).

\section{De functie van het citaat}

Het citaat (inclusief van) in de heb-zoiets-van-constructie lijkt dus een parenthetisch geïnserteerd adjunct. De functie van thematisch object wordt ingevuld door iets, een approximatieve betekenis wordt gerealiseerd door zo, en het citaat wordt aangekondigd door de quotatiefmarkeerder van. Maar wat is dan de functie van het citaat? Net als het citaat bij de reporting clauses zal het anaforisch verbonden zijn met het thematisch object, en als zodanig aansluiten bij die betekenis. Maar betekent dit ook dat het citaat een citaat is?

De subtiele betekenis van de heb-zoiets-van-constructie blijkt pas duidelijk, als we de volgende zinnen vergelijken:

(85) Hij zei: “Geef die appelmoes nou eens door!"

(86) Hij zei van: "Geef die appelmoes nou eens door!"

(87) Hij zei zo van: "Geef die appelmoes nou eens door!"

(88) Hij zei zoiets van: "Geef die appelmoes nou eens door!"

(89) Hij had zoiets van: "Geef die appelmoes nou eens door!" 
Het verschil tussen (85-88) is relatief klein, maar het verschil met (89) is groot: de laatste zin is de enige waarin er geen sprake van is dat het subject hij daadwerkelijk iets zegt. Waar in (85) een precieze weergave van het gesprokene aangeduid wordt, lijkt daar in (86) een extra betekenisaspect bij te komen: blijkbaar is "Geef die appelmoes nou eens door!" een vaker gebruikte, typische uitspraak. Dit komt overeen met wat Mazeland (2006) typification noemt: het quotatieve van maakt het citaat een voorbeeld van een uitspraaktype in plaats van een letterlijke weergave van een uitspraak.

In (87) voegt zo daar nog een approximatieve betekenis aan toe, die in (88) nog enigszins versterkt lijkt, wellicht door de associatie met een partitief. Maar in (89) wordt niet meer gesproken. Daar lijkt het of de spreker uit de signalen die het subject hij geeft de indruk afleidt dat die een gevoel heeft dat benaderd wordt door de typische uitspraak "Geef die appelmoes nou eens door!" Pascual (2002) schaart deze constructie dan ook onder de "fictitious dialogue." De uitspraak is verzonnen om het gevoel te karakteriseren.

Beide aspecten (typificatie en het approximatieve zo) doen een beroep op gezamenlijke kennis, en versterken elkaar dus in dit opzicht. Van (86) kan al gezegd worden dat het appeleert aan een algemeen idee van waar het citaat voor staat, in (87) wordt dat appel nog versterkt.

Dat het nou juist een citaat is dat deze functie vervult, kan verklaard worden door te stellen dat de directe rede in deze constructie letterlijk de innerlijke stem citeert. In (89) wordt mijns inziens via een directe rede weergegeven wat de spreker veronderstelt dat het subject bij zichzelf zegt. De spreker verplaatst zich blijkbaar op grond van allerlei signalen in de ander, en rapporteert wat deze bij zichzelf zegt.

Deze verklaring is ook toepasbaar op de gevallen waarin het subject en de spreker samenvallen:

(90) Ik had zoiets van: "Geef die appelmoes nou eens door!"

Wie dit zegt, vertelt niet wat hij letterlijk gezegd heeft, en zelfs niet wat hij vindt, maar wat zijn innerlijke stem hem zei (en wat hij eventueel met nonverbale signalen aangaf).

Deze analyse leidt tot de volgende uiteindelijke inheritance tree:

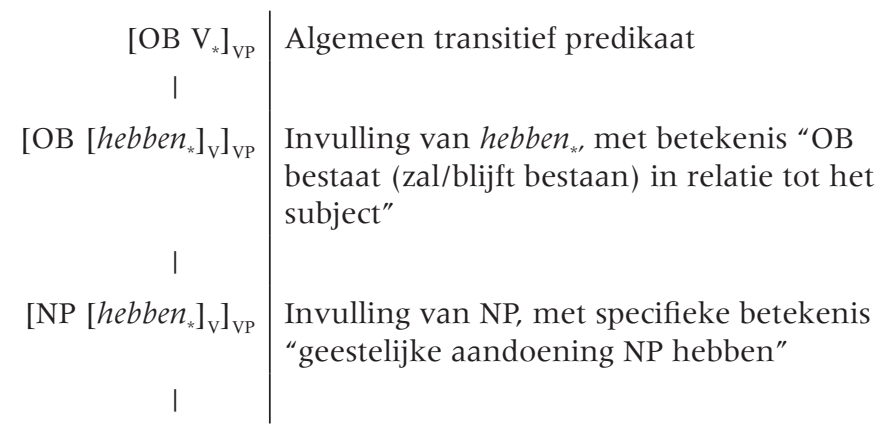




\begin{tabular}{|c|c|}
\hline$\left[\left[(z o) \text { iets } \mathrm{AP}_{\mathrm{GEN}}\right]_{\mathrm{NP}}\left[\text { hebben }_{*}\right]_{\mathrm{V}}\right]_{\mathrm{VP}}$ & $\begin{array}{l}\text { Invulling van de NP met (zo) iets+partitieve } \\
\text { genitief, met de betekenis "(bij benadering) } \\
\text { iets hebben van de geestelijke aandoening } \\
\text { AP" }\end{array}$ \\
\hline I & \\
\hline$\left[\left[(z o) \text { iets }[\text { van } \mathrm{X}]_{\mathrm{PP}}\right]_{\mathrm{NP}}[\text { hebben }]_{\mathrm{V}}\right]_{\mathrm{VP}}$ & $\begin{array}{l}\text { Vervanging van de partitieve genitief door } \\
\text { een PP met van }\end{array}$ \\
\hline I & \\
\hline$\left.\left[[(\text { zo }) \text { iets }]_{\mathrm{NP}}[\text { hebben }]_{*}\right]_{\mathrm{V}}[\text { van CP }]_{\mathrm{PP}}\right]_{\mathrm{VP}}$ & $\begin{array}{l}\text { Invulling van het element } X \text { met een quota- } \\
\text { tie (citaat) in zinsfinale positie, met als bete- } \\
\text { kenis: "(bij benadering) iets hebben van een } \\
\text { geestelijke aandoening die leidt tot het citaat } \\
\text { CP van de innerlijke stem" }\end{array}$ \\
\hline
\end{tabular}

\section{Conclusie}

In dit artikel herleid ik het constructionele idioom zoiets hebben van CP tot een inheritance tree in het kader van de constructiegrammatica, waarin de relatie met verschillende andere constructies is uitgedrukt. De componenten zijn als volgt te omschrijven:

- Hebben (met varianten krijgen en houden) fungeert als een transitief betekenisarm werkwoord om aan te geven dat het subject een gevoel overkomt;

- Iets is het syntactisch noodzakelijke object, omdat hebben geen directe rede als object verdraagt;

- $\quad$ Zo appelleert aan gezamenlijke kennis en roept aldus een approximatieve betekenis op;

- Van is een variant van de invulling van een partitieve genitief in de voorgaande constructie, en krijgt de functie van quotatiefmarkeerder;

- $\quad$ De directe rede citeert (of: construeert) de (fictieve) innerlijke stem, die het gevoel weergeeft (en vaak abstraheert tot een voorbeeld van een typische uitspraak).

De inheritance tree komt overeen met de waarschijnlijke historische ontwikkeling van de constructie, maar is ook te lezen als een beschrijving van het synchrone netwerk van relaties die de heb-zoiets-van-constructie onderhoudt met andere constructies in het hedendaagse Nederlands: alle componenten in de inheritance tree betreffen bestaande, en tamelijk gebruikelijke constructies.

De analyse bevestigt de in de literatuur reeds gedane suggesties dat de elementen van de heb-zoiets-van-constructie al langer bestaan, sommige zelfs veel langer dan tot nog toe werd aangenomen. Zo blijkt hebben met een (bij voorkeur negatief) gevoelsobject al eeuwenoud, evenals de quotatiefmarkeerder van. De geschiedenis van het quotatieve zoiets van blijkt terug te voeren tot halverwege de negentiende eeuw. De vindplaatsen suggereren zelfs dat het destijds in de spreektaal bepaald niet ongewoon was. Al met al is het opmerkelijk te noemen dat de totale constructie pas vanaf de laatste helft van de twintigste eeuw geattesteerd is, aangezien alle componenten al veel verder kunnen worden terug- 
gevoerd. ${ }^{13}$ Blijkbaar past de hedendaagse combinatie van bestaande ingrediënten in een mondiale trend van quotatiefmarkering (zie voor een uitgebreide argumentatie voor deze trend Foolen 2008).

Opmerkelijk is ten slotte nog dat de constructie bij het grote publiek in een kwade reuk staat. Het is een van de meest gewraakte constructies in het hedendaagse Nederlands, die steevast in de top tien van taalergernissen terechtkomt. Hoewel de taalkritiek waarmee deze attitude gepaard gaat geen taalwetenschappelijke gronden heeft, biedt de taalkundige analyse wel aanknopingspunten voor een verklaring. Ten eerste betreft het blijkbaar een recente constructie, die als gevolg van een mondiale trend tot quotatiefmarkering ook een redelijke frequentie vertoont, en vanwege zijn recente karakter vooral bij jongere generaties populair is. Ten tweede doet de constructie een beroep op gezamenlijke kennis (met het woordje zo). Dat kan uitgelegd worden als gemakzucht van de spreker. Ten derde zit in de constructie een approximatieve betekenis opgesloten. Dat streven om precisie te benaderen kan gemakkelijk verkeerd worden opgevat als een poging om juist precisie te ontvluchten.

\section{Bibliografie}

Alphen, I. van (2006). Ik had zoiets van "doei". Interactioneel sociolinguïstische aspecten van van-citaties. In: T. Koole, J. Nortier \& B. Tahitu (red.), Artikelen van de Vijfde sociolinguïstische conferentie. Delft: Eburon, 29-42.

Collins, C. \& P. Branigan (1997). Quotative inversion. Natural Language and Linguistic Theory 15, 1-41.

Coppen, P.A. (1994). Zoiets als van Victor Borge. <www.neder-l.nl/archieven/miniatuurtjes/940401.html>

Craenenbroeck, J. Van (2000). Complementerend van. Nederlandse Taalkunde 5, 133163.

Craenenbroeck, J. Van (2002). Van as a marker of dissociation: Microvariation in Dutch. In: C.J.W. Zwart \& W. Abrahams (red.), Studies in comparative Germanic Syntax. Amsterdam: Benjamins, 133-163.

Foolen, A. (2006). Het performatieve van opnieuw beschouwd. In: T. Koole, J. Nortier en B. Tahitu (red.), Artikelen van de Vijfde sociolinguïstische conferentie. Delft: Eburon, 163-174.

Foolen, A. (2008). New quotative markers in spoken discourse. In: Bernt Ahrenholz et al. (red.), Empirische Forschung und Theoriebildung. Frankfurt am Main: Peter Lang, 117-128.

Foolen, A., I. van Alphen, E. Hoekstra, H. Lammers, H. Mazeland \& E. Pascual (2006). Het quotatieve van. Vorm, functie en sociolinguïstische variatie. Toegepaste Taalwetenschap in Artikelen 76, Thema's en trends in de Sociolinguistiek 5, 137-149.

13 Mijn eerdere opmerking dat het DBNL een snel uitdijend corpus is wordt bewaarheid door de constatering dat ik bij de laatste redactie van dit artikel nog een mooi voorbeeld tegenkwam van een voorbeeld dat de heb-zoietsvan-constructie wel heel dicht benadert. In de brieven van Vincent van Gogh (rond 1880) komt de volgende zin voor: "Ik dacht dus zoo iets van: neen, we zullen hem eerst wakker maken." Elders gebruikt hij ook de quotatieve constructie $i k$ voelde iets van. 
Goldberg, A. (1995). Constructions. A construction grammar approach to argument structure. Chicago \& Londen: Chicago University Press.

Hengeveld, K. (1994). Ik heb zoiets van: “Ze bekijken het maar!” In: F.G. van Werkgem (red.), Dubbel Nederlands: 23 opstellen voor Simon C. Dik. Dordrecht: ICG, 8-12.

Horst, J.M. van der (1982). VAN... een tipje van de sluier. Onze Taal 51, 88-89.

Horst, J.M. van der (2008). De geschiedenis van de Nederlandse syntaxis. Leuven: Universitaire Pers Leuven.

Jackendoff, R. (1995). The boundaries of the lexicon. In: Everaert, M., E.J. van der Linden, A. Schenk \& R. Schreuder (red.), Idioms, structural and psychological perspectives. Hillsdale NJ: Lawrence Erlbaum, 133-165.

Mazeland, H. (2006). "VAN" as a quotative in Dutch. In: T. Koole, T., J. Nortier \& B. Tahitu (Red.), Artikelen van de Vijfde sociolinguïstische conferentie. Delft: Eburon, 354365.

Overdiep, G.S. (1937). Stilistische grammatica van het moderne Nederlandsch. Zwolle: Tjeenk Willink.

Pascual, E. (2002). Imaginary trialogues. Conceptual blending and fictive interaction in criminal courts. Amsterdam: VU.

Schelfhout, C. (2000). Corpus-based analysis of parenthetical reporting clauses. In: F. Van Eynde, I. Schuurman \& N. Schelkens (reds.) Computational linguistics in the Netherlands 1998. Selected papers from the ninth CLIN Meeting, 47-59.

Schönfeld, M. (1970). Historische grammatica van het Nederlands. Editie A. Van Loey. Zutphen: Thieme \& Cie.

Toorn, M.C. van den, W. Pijnenburg, J.A. van Leuvensteijn en J.M. van der Horst (red.) (1997). Geschiedenis van de Nederlandse taal. Amsterdam: Amsterdam University Press.

Vandelanotte, L. (2008). The emergence and structure of be like and related quotatives: A constructional account. Preprint of the Department of Linguistics 267. Leuven: KU Leuven, Department of Linguistics.

Verhagen, A. (2005). Constructiegrammatica en 'usage based' taalkunde. Nederlandse Taalkunde 10, 197-222.

Verkuyl, H.J. (1976). Het performatieve van. Spektator 6, 481-483.

Verkuyl, H.J. (1979). Ik meen van niet. Onze Taal 48, 61-62.

Wouden, T. van der, H. Hoekstra, M. Moortgat, B. Renmans \& I. Schuurman (2002). Syntactische annotatie voor het Corpus Gesproken Nederlands. Nederlandse Taalkunde 7, 335-352. 